\title{
Implementation of knowledge management system in cattle farming
}

\author{
Edi Kusnadi a, 1; Yessy Yanitasari a, 2, "; Supriyadi a, 3 \\ a STMIK Kharisma, Jl. Pangkal Perjuangan KM 1(Bypass), Karawang 41316, Indonesia \\ 'edikusnadi914@gmail.com; ${ }^{2}$ yessy.yanitasari@gmail.com; ${ }^{3}$ supriyadi.krw@horizon.ac.id \\ * Corresponding author
}

Article history: Received February 10, 2021; Revised April 20, 2021; Accepted April 30, 2021; Available online April 30, 2021

\begin{abstract}
Cattle are the livestock of the Bovinae family and subfamily Bovidae. They have been raised for beef and dairy products. Nowadays, beef production does not meet national needs. This is influenced by several factors. One of them is the farming pattern. However, knowledge about cattle farming is still scattered and unstructured. Knowledge Management System (KMS) offers a knowledge system that can be used to create, collect, store, maintain and disseminate knowledge. In this study, KMS for cattle farming has been implemented using the Knowledge Management System Life Cycle (KMSLC) method. The research results are web-based applications regarding cattle farming management that have been tested by experts and users, with the average test results declared good. The features possessed by this KMS application are knowledge capture, knowledge sharing, and knowledge application systems so that they can share knowledge between one user and another. In addition, this application is equipped with a discussion forum that can serve as a place to interact with fellow users or with experts.
\end{abstract}

Keywords: Cattle; Farming; Knowledge; KMS; KMSLC.

\section{Introduction}

Cattle are the livestock of the Bovinae family and subfamily Bovidae. They have been raised for beef and dairy products to fulfill human needs. Besides, in several places, cattle are also used as a means of transportation, cultivation of land for planting (plow), and other industrial tools such as sugar cane squeezers. Other products from cattle such as the skin, offal, horns, and dung are also used for various human purposes. The demand for beef does not match the beef production itself. Nationally, the demand for beef that can be fulfilled which is in 2015 was recorded at 506,661 tons out of a total of 613,110 tons [1], in 2016 it was recorded at 518,484 tons from a total of 597,608 tons [2], in 2017 it was recorded at 486,320 tons from a total of 657,608 tons, in 2018 it was recorded at 497,972 tons of a total of 662,538 tons [3] and in 2019 there were 490,421 tons out of a total of 683,290 tons [4], it means that the remaining needs must be imported from abroad. The decline in beef production is due to several factors. One of them is the farming pattern. Farming is a good and profitable business [5]. To increase the success in cattle farming, it is necessary to know several factors, including grazing systems, cages, nurseries, feed, and must also know the types of cattle diseases and how to prevent them [6]. Cattle farming can be developed into knowledge management by implementing a Knowledge Management System (KMS).

KMS is a set of processes built within the company to create, collect, store, maintain and disseminate knowledge owned by the company [7]. For this reason, knowledge management is needed to be more structured and make it easier to search data. One of the knowledges that needs to be managed is in the field of cattle farming. Knowledge of cattle farming can be acquired from the internet, books, e-books, and counseling. However, this is less effective because the data is still scattered and unstructured. Therefore, in-depth research on cattle farming is needed. As for research on cattle farming, Ali and Muwakhid [8] stated that the types of bulls that are often raised are Simmental and limousine breeds. According to Sandi et al [9], the types of beef cattle raised are Bali cattle and Ongole crossbred cattle. The Bali cattle are often raised [10]. The pattern of raising beef cattle can be made with a semi-intensive system. In the morning, the cattle are grazed, and in the afternoon, the cattle return to the cage [11]. An essential factor in the success of a cattle farming business is to know about animal feeding, livestock raising, building cages, reproduction, and breeding cattle [12]. The forage availability is also one of the determining factors for the success of the cattle business [13]. According to Ngadiyono et al [14] things that need to be learned in beef cattle farming are breed 
selection, simple recording, disease prevention, and reproductive management. Meanwhile, according to Said et al. [15] the optimization of the livestock production process is determined by several factors, including feeding, breeding, and aspects of governance (management). It is necessary to create a system for cattle farming management to learn the management pattern. KMS is a knowledge management system with a classification including being able to share knowledge through an application that provides download or upload features. Research on the topic of KMS has been carried out by Yanitasari et al. [16]. They stated that implementing KMS can provide recommendations for selecting effective fertilizers based on knowledge obtained from experts (tacit) or knowledge in explicit form. In addition, the application of KMS can gain understanding to support decision-making in developing an education business and obtain data in the form of measuring the level of customer decisions [17].

Based on the description of the problem, it is necessary to have a system that can accommodate knowledge about cattle farming, starting from selecting breeds, feeding, selecting of cages, raising systems, and types of beef cattle. KMS has been known as a computerized technique for gathering knowledge into a computer system. In this case, the application of KMS is needed to make it easier for cattle farmers in cattle farming management. The information will be obtained by involving cattle experts and through observation. The KMS development method used is the Knowledge Management System Life Cycle (KMSLC) method, which consists of several stages, including evaluate existing infrastructure, form the KM team, knowledge capture, design KM blueprint, verify and validate the KM system, implement KM system, manage change, and post system evaluation [18]. The analysis model uses an Object-Oriented Approach (OOA) and is web-based. At the same time, the storage database uses MySQL with the PHP programming language [19].

\section{Method}

This research uses the KMSLC method where only 6 stages are used: Evaluate Existing Infrastructure, Form the KM Team, Knowledge Capture, Design KM Blueprint, Verify and Validate the KM System, Implement the KM System. The explanation of each stage of the method is as follows, and the stages of the KMSLC method is shown in Figure 1.

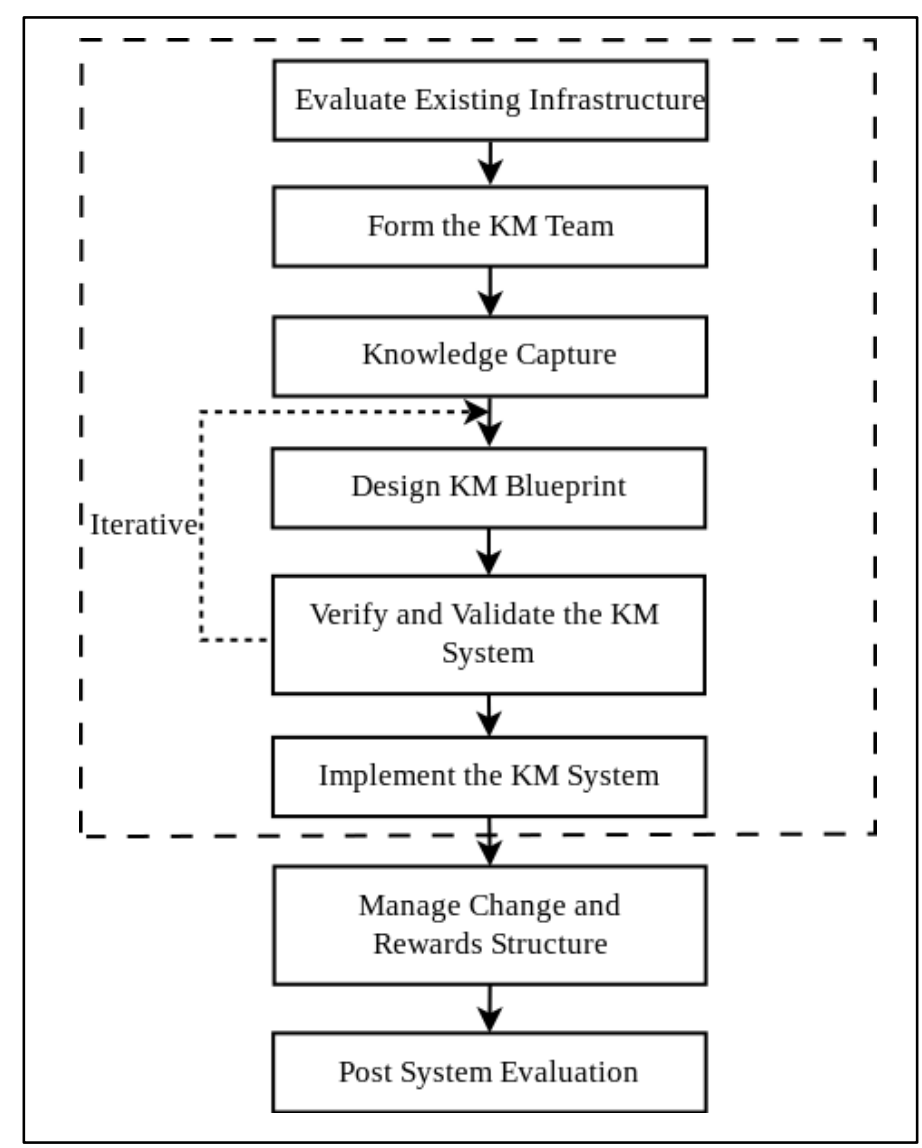

Figure 1. KSMLC [18]

\section{A. Evaluate Existing Infrastructure}

It is the process of evaluating the existence of the available infrastructure and needed for system development. These include financial, human resources, operational standards [18]. 


\section{B. Form the KM Team}

Identification of resources for KMS development is made by forming a KM team.

\section{Knowledge Capture}

Identify and capture sources of knowledge in the form of tacit knowledge from cattle experts through interviews, on-site observation, and explicit knowledge.

\section{Design KM Blueprint}

1. Knowledge Codification Design

Codification of knowledge means converting tacit knowledge into the form of explicit knowledge used for organizational members to be converted into document form. The knowledge tool or procedure used is in the form of a knowledge map.

2. Knowledge Management System Architecture Design

The knowledge management system architecture design refers to seven layers: user interface, authorized access control, collaborative intelligence and filtering, knowledge enabling application, transport, middleware, and the physical layer [18].

3. Model System Design

The designs represented are use case diagrams, class diagrams, domain class diagrams, sequence diagrams, and user interface designs [19].

\section{E. Verify and Validate the KM System}

Perform verification and validation by knowledge testing. There are two types of knowledge testing: logical testing and user acceptance testing [18].

\section{F. Implement the KM System}

The KMS developed is a web-based computer application with a client-server system.

\section{Results and Discussion}

\section{A. Evaluate Existing Infrastructure}

The following are the results of the infrastructure evaluation listed in Table $\mathbf{1 .}$

Table 1. Results of Evaluate Existing Infrastructure

\begin{tabular}{|l|l|l|}
\hline No & Infrastruktur & Hasil Evaluasi Ketersediaan Infrastruktur \\
\hline 1 & Hardware & $\begin{array}{l}\text { A computer system that has been equipped with adequate input and output devices to } \\
\text { implement KM in cattle farming. }\end{array}$ \\
\hline 2 & Software & $\begin{array}{l}\text { A computer that has an operating system installed and several software such as: mozilla } \\
\text { firefox, google chrome, xampp, sublime text and office application software }\end{array}$ \\
\hline 3 & Netware & Using the internet network. \\
\hline 4 & Brainware & Experts in the field of computers and cattle experts. \\
\hline 5 & Dataware & $\begin{array}{l}\text { Data from interviews with cattle experts, scientific literature such as books, journals and } \\
\text { e-books. }\end{array}$ \\
\hline 6 & Process & The data is documented into a database by computer experts. \\
\hline
\end{tabular}

\section{B. Form the KM Team}

The following is an explanation of the KM team resources in Table 2:

Table 2. Form the KM Team

\begin{tabular}{|l|l|l|l|}
\hline No & KM Team & Human resources & Information \\
\hline 1 & Cattle Expert & $\begin{array}{l}\text { Expert from Karawang Agriculture Service: } \\
\text { Slamet Yuliyadi, S.PKP., M.P }\end{array}$ & A person who is knowledgeable for about cattle. \\
\hline 2 & $\begin{array}{l}\text { Developer of } \\
\text { KMS }\end{array}$ & $\begin{array}{l}\text { 1. Edi Kusnadi (Analysis and design, and } \\
\text { programmer) } \\
\text { 2. Yessy Yanitasari, S.T., M.Kom (Analysis and } \\
\text { design) } \\
\text { 3. Supriyadi, S.T., M.Kom (Analysis and design) }\end{array}$ & The person who develops KMS for cattle farming \\
\hline 3 & Admin & $\begin{array}{l}\text { IT staff / employees of the Karawang Agriculture } \\
\text { Andri Nurochman }\end{array}$ & $\begin{array}{l}\text { A person who has full access rights to the KMS } \\
\text { system for cattle farming. }\end{array}$ \\
\hline 4 & Members & Cattle farmers & $\begin{array}{l}\text { People who seek knowledge about cattle and } \\
\text { register as members. }\end{array}$ \\
\hline 5 & Guests & Cattle farmers & $\begin{array}{l}\text { People who seek knowledge about cattle without } \\
\text { registering as a member. }\end{array}$ \\
\hline
\end{tabular}




\section{Knowledge Capture}

The results of identifying sources of knowledge from cattle experts are shown in Table $\mathbf{3}$ and explained as follows:

1. Literature study by conducting studies on relevant scientific works, beef cattle farming technology books [6], beef cattle farming books [20], and beef cattle fattening books [21].

2. 2. Direct interviews with experts, either with structured questions or free questions. The questions asked are related to the definition of beef cattle, types of beef cattle, raising systems, types of cages and types of feed.

3. 3. On-site observation technique, a technique of capturing knowledge by observing, recording, and interpreting the problem-solving process carried out by cattle experts.

Table 3. Results of Knowledge Transformation of Cattle farming

\begin{tabular}{|l|l|l|}
\hline To & \multicolumn{2}{|c|}{ Result } \\
\hline From & Tacit & Explicit \\
\hline \multirow{2}{*}{ Tacit } & $\begin{array}{l}\text { 1. } \begin{array}{l}\text { Conduct discussions and interviews with cattle experts. } \\
\text { 2onduct presentations and discussions with cattle } \\
\text { experts. }\end{array} \\
\begin{array}{l}\text { 3. Perform knowledge data entry and upload new } \\
\text { documents. }\end{array}\end{array}$ & $\begin{array}{l}\text { 1. Print the document in paper form. } \\
\text { Knowledge data is stored in the KMS database for } \\
\text { cattle farming by using the MySQL DBMS. }\end{array}$ \\
\hline Explicit & $\begin{array}{l}\text { 1. } \begin{array}{l}\text { Evaluation of documents by experts. } \\
\text { New knowledge found in the field is stored in the } \\
\text { database. }\end{array} \\
\text { 1. Paper documents become digital documents. }\end{array}$ \\
\hline
\end{tabular}

\section{Design KM Blueprint}

1. Knowledge Codification Design

The result of knowledge codification on the research by using the Knowledge Map. For the initial process of forming a K-Map, it is determined by the concept level as shown in Table 4.

Table 4. Results of K-Map Forming Process Levels

\begin{tabular}{|c|l|l|l|}
\hline No & Level & Name & Sub Level / Child Concept \\
\hline 1 & Top Level & Breeding systems & Breeding and fattening \\
\hline 2 & Sub Level 1.1 & Breeding & $2-3$ years old \\
\hline 3 & Sub Level 1.1 .1 & $2-3$ years old & Local cattle \\
\hline 4 & Sub Level 1.1 .1 .1 & Local cattle & Extensif, semi intensif, intensif \\
\hline 5 & Sub Level 1.2 & Fattening & Usia 1,5 - 2 tahun \\
\hline 6 & Sub Level 1.2 .1 & $1,5-2$ years old & Exotic and crossbred cattle \\
\hline 7 & Sub Level 1.2 .1 .1 & Exotic and crossbred cattle & Intensive \\
\hline 8 & Sub Level 4.1 & Extensive & Individual Cage, Collective Cage \\
\hline 9 & Sub Level 4.2 & Semi intensive & Individual Cage, Collective Cage \\
\hline 10 & Sub Level 4.3 & Intensive & Individual Cage, Collective Cage \\
\hline 11 & Sub Level 5.1 & Individual Cage & Concentrate feed, Forage feed \\
\hline 12 & Sub Level 5.2 & Collective Cage & Concentrate feed, Forage feed \\
\hline 13 & Sub Level 6.1 & Concentrate feed & Farming production \\
\hline 14 & Sub Level 6.2 & Forage feed & Farming production \\
\hline 15 & Sub Level 7.1 & Farming production & - \\
\hline
\end{tabular}

From the process of forming the concept of the K-Map level above, it produces a visual representation of the K-Map codification of cattle farming as shown in Figure 2.

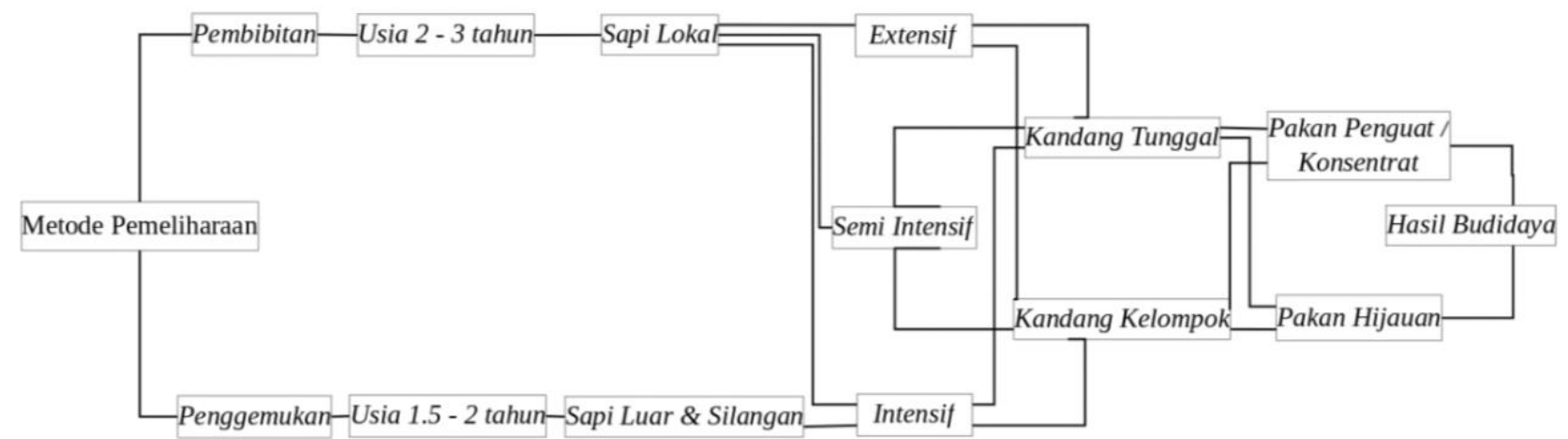

Figure 2. Knowledge Map of cattle farming 
2. Knowledge Management System Architecture Design

The results of the KMS architectural design are shown in Figure 3.

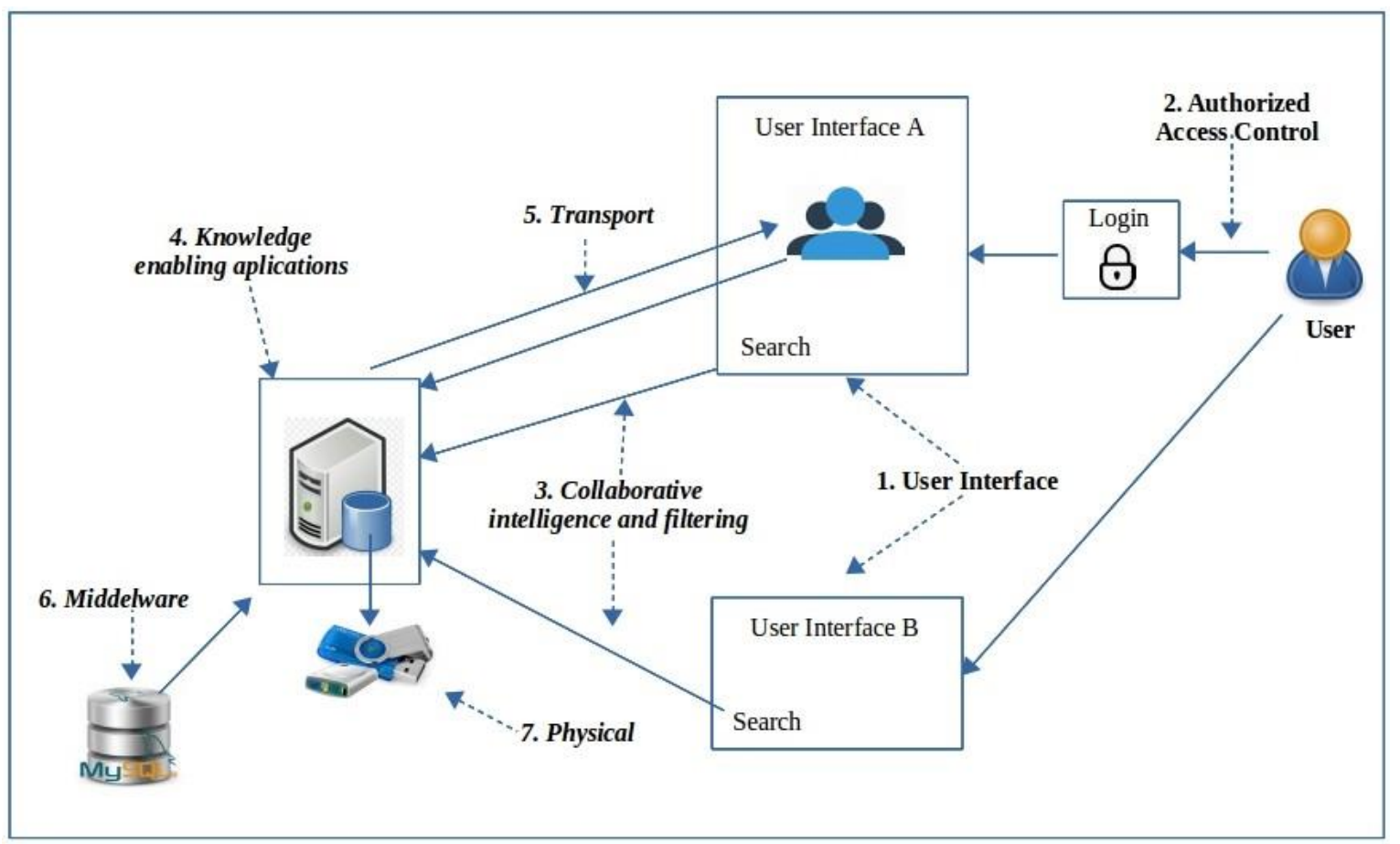

Figure 3. Adoption of KMS Architectural Design [16]

3. Model Design System

a. Use Case Diagram

The following is a use case diagram of managing knowledge shown in Figure 4.

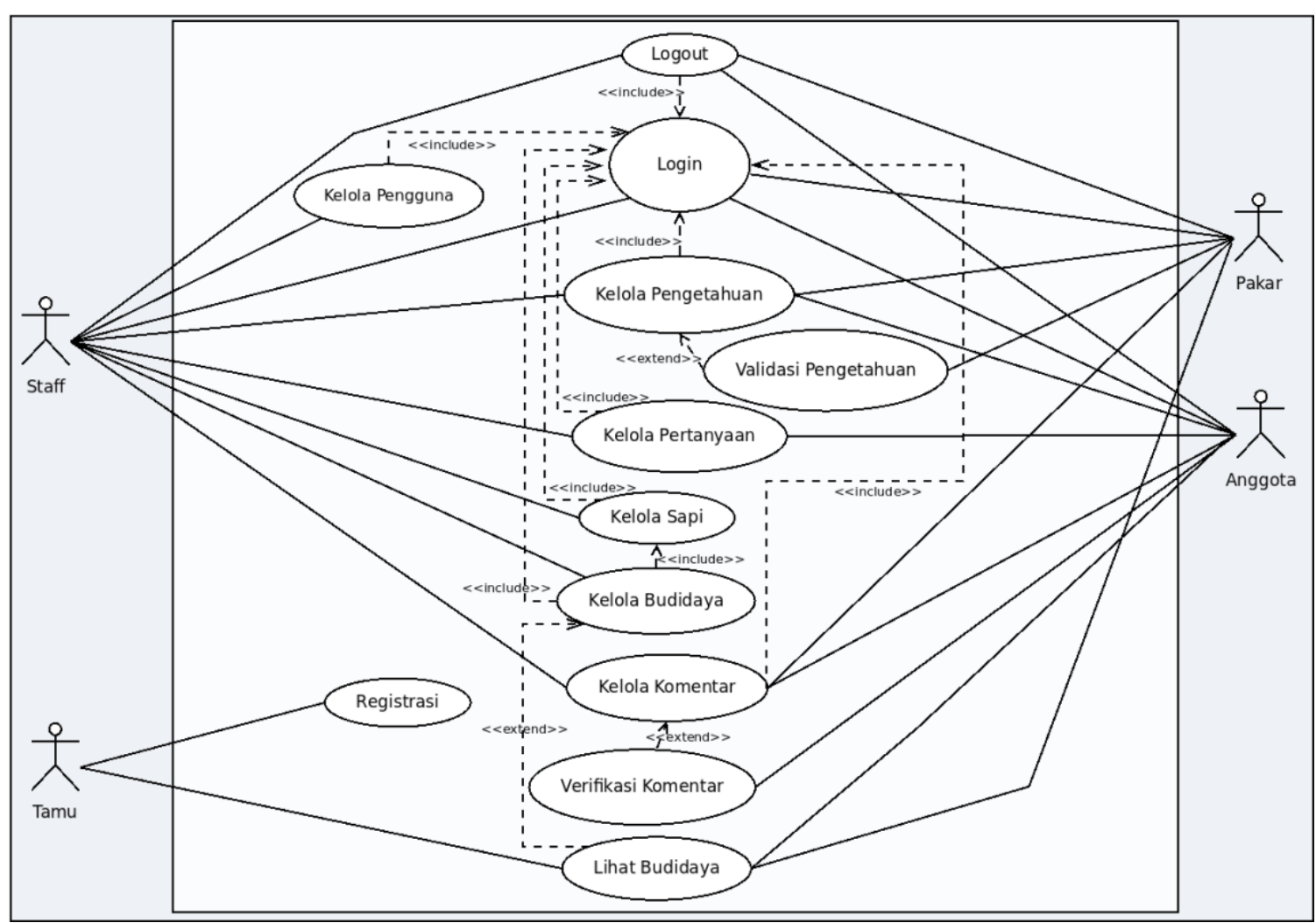

Figure 4. Use Case Diagram 
b. Class Diagram

The following is a class diagram of managing knowledge shown in Figure 5.

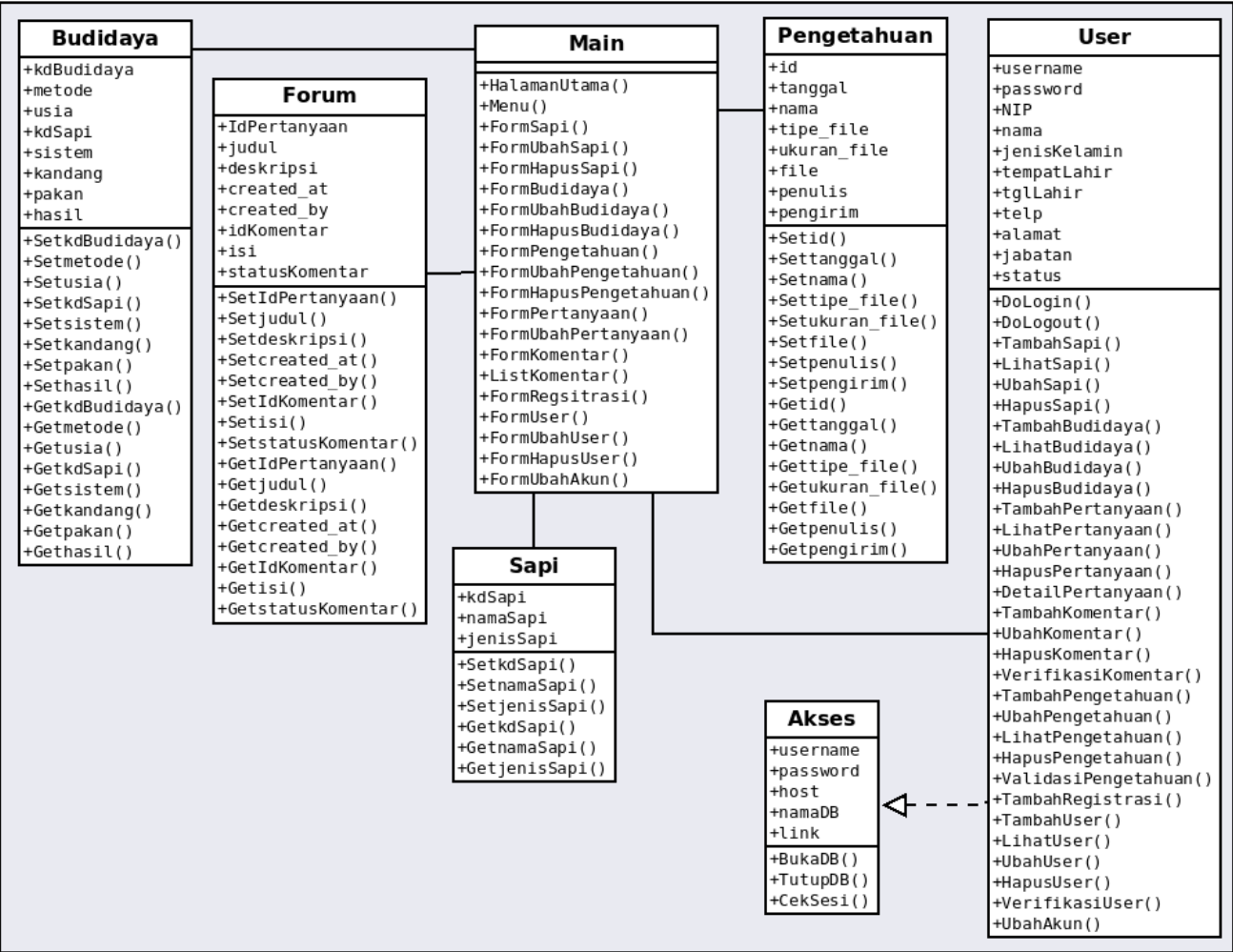

Figure 5. Class Diagram

c. Program View

The following is the main user page for the program of the knowledge management system application for cattle farming as shown in Figure 6.

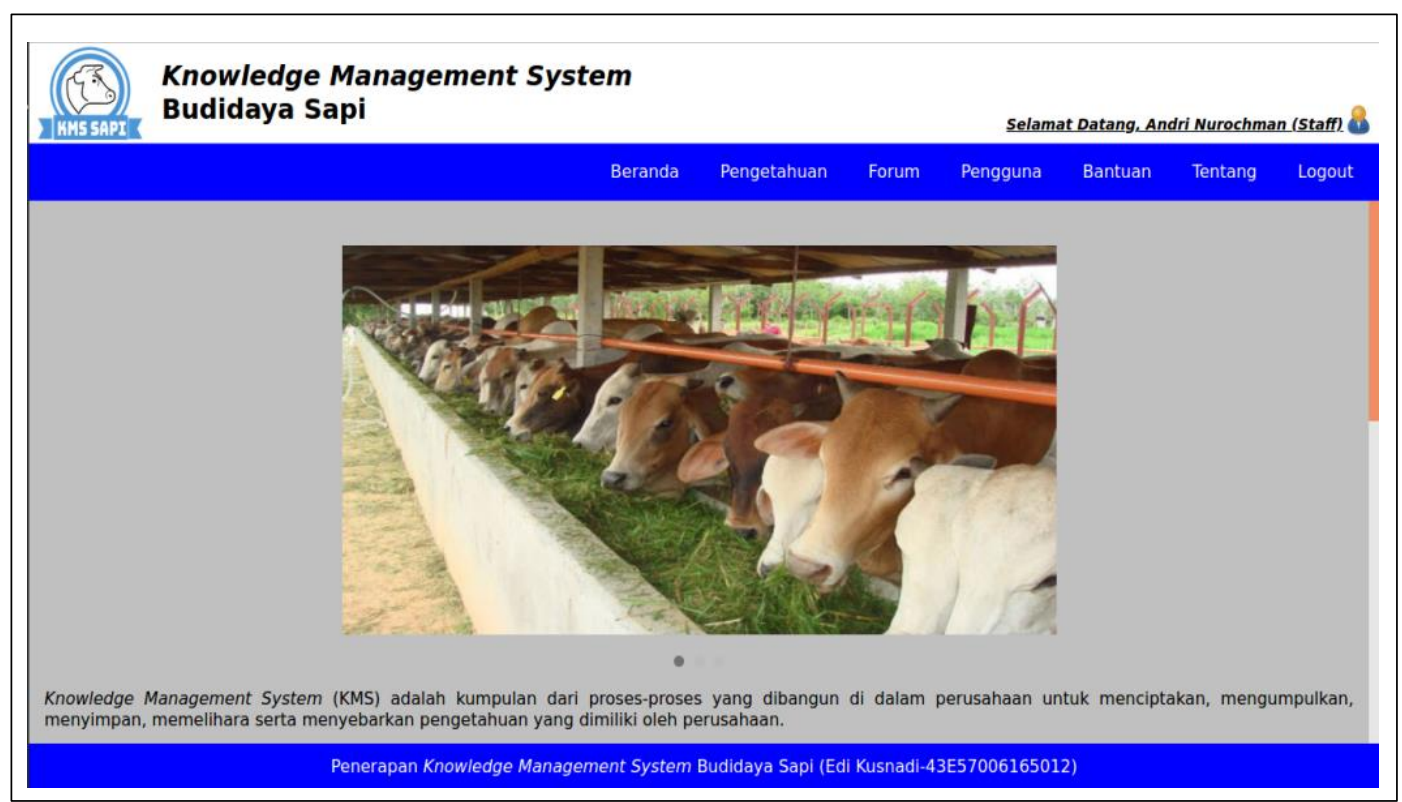

Figure 6. Main Page User Interface

\section{E. Verify and Validate the KM System}

The results of KMS verification and validation are as follows:

1. Logical Testing 
Tested by the developer (programmer) shown in Table $\mathbf{5}$ and some of the logical attributes used are as follows:

a. Circular rules

Here's the program code:

<?php require once "../class/ClassAkses.php"; require once "../ClassMain.php"; \$akses= new Akses; \$akses->CekSesi (); \$main = new Main; \$main-

$>$ FormPengetahuan (); ?>

b. Redundancy

Here's the program code:

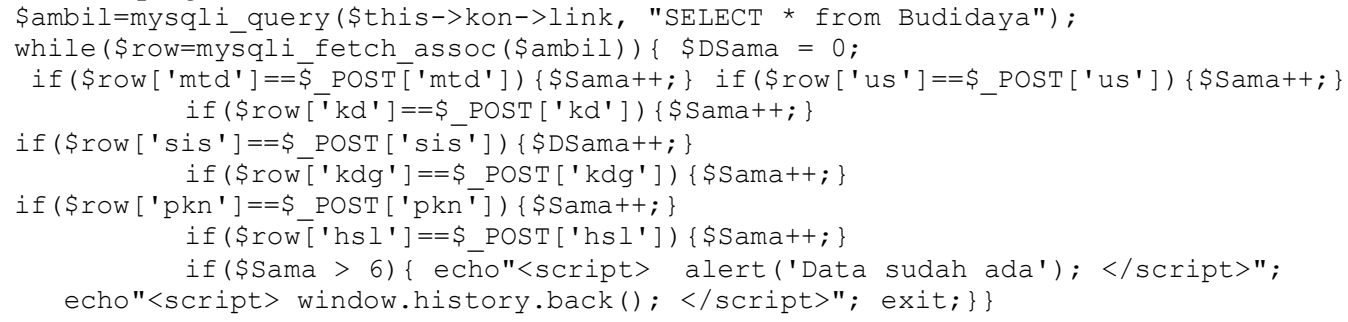

c. Equipment

Here's the program code:

\$ambil = mysqli_query ( this->kon->link);

if (\$ SESSION['group'] == 'Anggota' \&\& \$kunci != '') \{

\$ambil = mysqli_query(\$this->kon->link, "select a.kdBddaya, a.metode, a.usia,

a.sistem, a.kandang, a.pakan, a.hasil, b.nmSapi from Budidaya as a, Sapi as b where

a.kdSapi = b.kdSapi AND (metode like '\$k\%' or usia like '\$k\%' or nmSapi like '\$k\%'

or sist like '\$k' or kdg like '\$ko' or pak like '\$k응 or hsl like '\$k\%")"); \}

d. Consistency, truth, confidence, reliability

To get consistent, correct, accurate and reliable answers, all knowledge is validated by experts through functions that are already available in the program menu. The validation results state that the knowledge stored in this knowledge database has been declared valid and following expert knowledge.

Table 5. Logical Testing Attribute Results

\begin{tabular}{|c|c|c|c|c|}
\hline No & Attribute & Questions & $\begin{array}{l}\text { KM } \\
\text { Team }\end{array}$ & Results \\
\hline 1 & $\begin{array}{l}\text { Circular } \\
\text { Rule }\end{array}$ & Is there a circular error in this system? & Programmer & OK \\
\hline 2 & Redundancy & Is there data redundancy in this system? & Programmer & OK \\
\hline 3 & Equipment & Can knowledge data be found in all knowledge tables in this system? & Programmer & OK \\
\hline 4 & Consistency & $\begin{array}{l}\text { Are the answers consistent and similar for each user of the knowledge search } \\
\text { facility? }\end{array}$ & Programmer & $\mathrm{OK}$ \\
\hline 6 & Confidence & Is the user's belief in the system solution based on validation? & Programmer & $\mathrm{OK}$ \\
\hline 7 & Reliability & $\begin{array}{l}\text { Has the durability of the database, the speed of searching and exchanging data } \\
\text { in the network have been tested? }\end{array}$ & Programmer & Untested \\
\hline
\end{tabular}

2. User Acceptance Test

Tested by experts, staff, members, and guests as shown in Table 6.

Table 6. User Acceptance Test Attribute Results

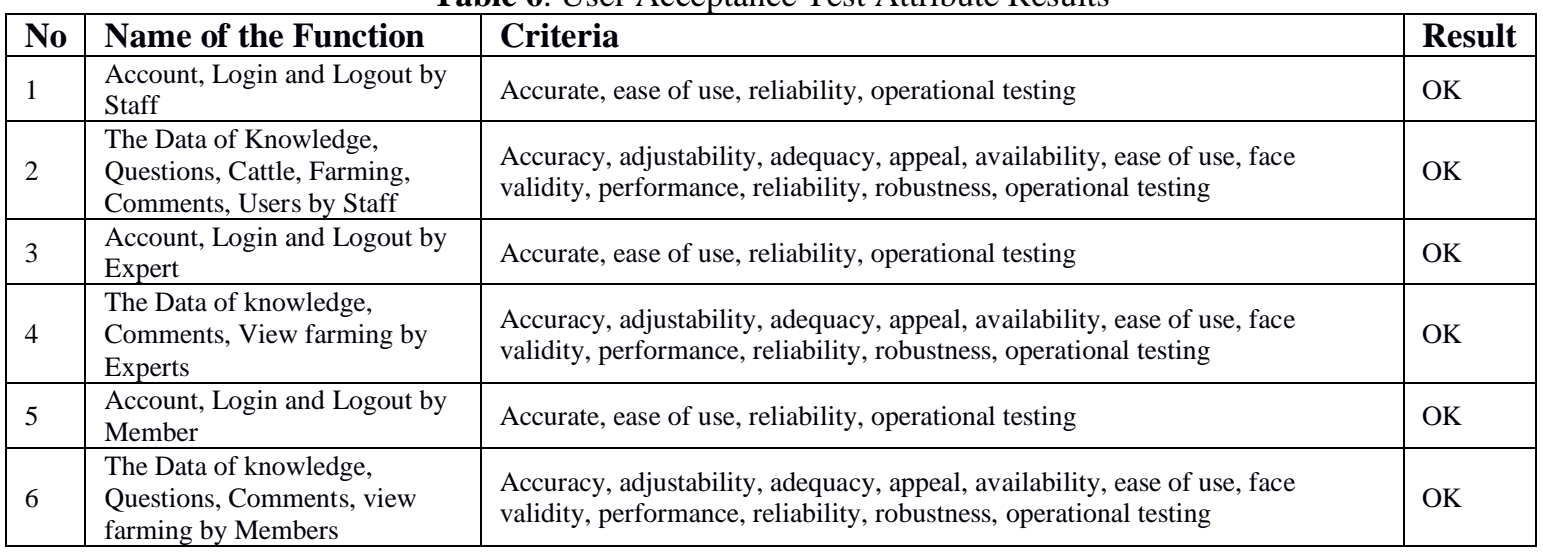




\begin{tabular}{|l|l|l|l|}
\hline No & Name of the Function & Criteria & Result \\
\hline 7 & Registration & Adjustability, ease of use, performance, operational testing & OK \\
\hline 8 & See Farming Guest & $\begin{array}{l}\text { Accuracy, adjustability, adequacy, appeal, availability, ease of use, face } \\
\text { validity, performance, reliability, robustness, operational testing }\end{array}$ & OK \\
\hline
\end{tabular}

\section{F. Implement the KM System}

The KMS implementation is carried out on two sides: on the client and server sides.

1. Server-side installation

Several applications have been installed, which are divided into 3 main groups, namely Apache web server, MySQL DBMS server, and script server using PHP hypertext preprocessor.

2. Installation on the client-side

A web browser has been installed as an interface. For optimal results from the system display side, it is recommended to use the Google Chrome web browser and the Mozilla Firefox web browser.

\section{Conclusion}

By creating this application, it is expected that it will make it easier for cattle farmers to find data about cattle farming, while the features for this application are as follows: 1) The application developed is KMS for cattle farming using the web based KMSLC method. 2) This application has accommodated knowledge of cattle farming obtained from tacit knowledge (expert knowledge) and explicit (knowledge from books, journals, and e-books). 3) In this application, 11 types of beef cattle have been recorded, consisting of 6 types of local beef cattle, 5 types of external beef cattle and crosses, and farming guidelines ranging from breeding methods to farming results.

\section{Acknowledgement}

Thank you to Mr. Slamet Yuliyadi, S.PKP., M.P as an expert on cattle farming at the Karawang Agriculture Service.

\section{Reference}

[1] [Pusdatin : Pusat Data dan Sistem Informasi Pertanian .id], 2016. Outlook Daging Sapi. ISSN : 1907-1507. Pusat Data dan Sistem Informasi Pertanian. Jakarta.

[2] __ 2017. Outlook Daging Sapi. ISSN : 1907-1507. Pusat Data dan Sistem Informasi Pertanian. Jakarta.

[3] —— 2018. Outlook Daging Sapi. ISSN : 1907-1507. Pusat Data dan Sistem Informasi Pertanian. Jakarta.

[4] __ 2019. Outlook Daging Sapi. ISSN : 1907-1507. Pusat Data dan Sistem Informasi Pertanian. Jakarta.

[5] [KBBI : Kamus Besar Bahasa Indonesia .id], 2020. Kamus Versi Onlie. Website : http://kbbi.web.id. (diakses tanggal 01 Maret 2020).

[6] [Balitbangtan : Badan Penelitian dan Pengembangan Pertanian], 2008. Teknologi Budidaya Sapi Potong. ISBN : 978-979-1415-30-9. Bogor.

[7] K.C. Laudon., J.P. Laudon., 2012. Management Information System, 12ed: Prentice Hall, USA.

[8] U. Ali., B. Muwakhid., 2017. Upaya Pengembangan Sapi Potong Menggunakan Pakan Basal Jerami Padi Di Desa Wonokerto, Dukun, Gresik. Jurnal Dedikasi. Vol. 14. ISSN : 1693-3214.

[9] S. Sandi., M. Desriani., Asmak, 2018. Manajemen Pakan Ternak Sapi Potong di Peternakan Rakyat di Desa Sejaro Sakti Kecamatan Indralaya Kabupaten Ogan Ilir. Jurnal Peternakan Sriwijaya. Vol. 1, No. 1. ISSN : 2303-1093.

[10]Z. Dady., C.L. Kaunang., Y.L.R. Tulung., 2018. Potensi Pengembangan Ternak Sapi Dengan Pola Terintegrasi Kelapa-Sapi Di Kecamatan Tabaru Kabupaten Halmahera Barat. Jurnal Agri Sosio Ekonomi Unsrat. Vol. 14 No. 1. ISSN : 1907- 4298.

[11] T.P. Daru., H. Pagoray., Suhardi, 2016. Pemanfaatan Lahan Pasca Tambang Batubara Sebagai Usaha Peternakan Sapi Potong Berkelanjutan. Jurnal Ziraa'ah. Vol. 41 No. 3. E-ISSN: 2355-3545.

[12]F.L. Syaiful., U.G.S. Dinata., Ferido, 2018. Pemberdayaan Masyarakat Nagari Sontang Kabupaten Pasaman Melalui Inovasi Budidaya Sapi Potong dan Inovasi Pakan Alternatif yang Ramah Lingkungan. Buletin Ilmiah Nagari Membangun. Vol. 1 No. 3. E-ISSN: 2622-9978.

[13] S. Rusdiana., U. Adiati., R. Hutasoit., 2016. Analisis Ekonomi Usaha Ternak Sapi Potong Berbasis Agroekosistem Di Indonesia. Jurnal Sosial Ekonomi dan Kebijakan Pertanian. Vol. 5 No. 2. P-ISSN : 2301-9948, E-ISSN : 24076260 .

[14] N. Ngadiyono., I.G.S. Budisatria., E. Baliarti., T.S.M. Panjono, Widi., M.D.E. Yulianto., B.A. Atmoko., 2019. Inisiasi Pengembangan Dan Pendampingan Peternakan Sapi Secara Terpadu Di Kelompok Ternak Sapi Kandang Kalimasodo. Jurnal Pengabdian dan Pemberdayaan Masyarakat. Vol. 3 No. 2. E-ISSN : 2549-8347, PISSN : 2579-9126.

[15] M.I. Said., F.N. Yuliati., M. Hatta., 2018. Aplikasi Teknologi Pakan Dan Pengolahan Limbah Ternak Pada Kelompok Peternak Sapi Pedaging Di Kabupaten Bantaeng. Jurnal Aplikasi Teknik dan Pengabdian Masyarakat. Vol. 2 No. 1. E-ISSN: 2550-0821. 
[16] Y. Yanitasari., I. Hermadi., W.A. Kusuma., 2015. Development of Fertilizer Selection using Knowledge Management System. TELKOMNIKA Indonesian Journal of Electrical Engineering. Vol. 13 No. 3. ISSN : 23024046.

[17] Y. Yanitasari., Supriyadi., 2017. Mapping CRM Dengan Menggunakan Importance Performance Analysis Pada KMS Customer Untuk Evaluasi Peningkatan Benefit Pendidikan. ILKOM Jurnal Ilmiah. Vol. 9 No. 2. P-ISSN : 2087-1716, E-ISSN : 2548-7779.

[18]E.M. Awad., H.M. Ghaziri., 2010. Knowledge Management. Prentice Hall.

[19] J.W. Satzinger., R.B. Jackson., S.D. Burd., 2012. System Analysis And Design In A Changing World. Course Technology, Cengage Learning. ISBN-13: 978-1-111-53415-8 ISBN-10: 1-111-53415-2. USA.

[20][BPTP Kalsel : Balai Pengkajian Teknologi Pertanian Kalimantan Selatan .id], 2010. Budidaya Sapi Potong. ISBN : 978-979-3112-32-9. Banjarbaru.

[21][BPTP Sulsel : Balai Pengkajian Teknologi Pertanian Sulawesi Selatan .id], 2016. Penggemukan Ternak Sapi Potong. Makasar. 